\title{
Feeding ecology of three juvenile mojarras (Gerreidae) in a tropical estuary of northeastern Brazil
}

\author{
Antônio Limeira Felinto de Araújo ${ }^{1}$, Renato Pereira Dantas² and \\ André Luiz Machado Pessanha
}

\begin{abstract}
Distributions and feeding ecology of mojarra species from shallow water of a tropical estuary in Northeastern Brazil were observed aiming to investigate differences in distribution and resource partitioning among juveniles of three species of mojarras. Fishes were collected with a beach seine across four sites along a salinity gradient from January to December of 2011. Highest abundances were recorded during the rainy season in the upper and middle estuary. Microcrustaceans, mainly copepods, were the preferential prey items of all mojarras, irrespective of size or hydrological season, suggesting these areas may be important nursery habitats. Juveniles of mojarra used two important mechanisms for exploitation of resources: (1) spatial segregation along the salinity and temperature gradient, such as abundance of Eucinostomus melanopterus increased from downstream to upstream estuary, while Eugerres brasilianus displayed an opposite pattern; (2) differences related to the volumetric proportion of the main prey items, with indications that $E$. melanopterus and Diapterus rhombeus fed predominantly on Calanoida and Cyclopoida, while the diet of E. brasilianus was dominated by items of infauna. Such strategies were important for resource partitioning, favouring the coexistence of these three species in the estuary.
\end{abstract}

A distribuição e a ecologia alimentar de gerreídeos capturados em águas rasas de um estuário tropical no nordeste do Brasil foram abordados com o objetivo de investigar diferenças na distribuição e partição de recursos entre três espécies de gerreídeos juvenis. Arrastos de praia foram realizados ao longo de quatro locais ao longo do gradiente de salinidade entre janeiro e dezembro de 2011. Maiores abundâncias foram registradas durante a estação chuvosa na zona superior e média do estuário. Microcrustáceos, principalmente copépodos, foram as principais presas para as três espécies, independente do tamanho ou do período hidrológico, sugerindo que essas áreas são importantes para o recrutamento. Gerreídeos juvenis usaram dois importantes mecanismos para exploração dos recursos: (1) segregação espacial no uso dos habitats ao longo do gradiente de salinidade e temperatura, com a abundância de Eucinostomus melanopterus aumentando em direção a parte inferior para porção superior do estuário, enquanto Eugerres brasilianus apresentou um padrão oposto; e (2) diferenças relacionadas com a proporção volumétrica das principais presas ingeridas, com indicações que E. melanopterus e Diapterus rhombeus alimentaram-se principalmente de Calanoida e Cyclpoida, enquanto a dieta de E. brasilianus foi dominada por itens da infauna. Tais estratégias foram importantes para partição dos recursos, favorecendo a coexistência dessas três espécies no estuário.

Keywords: Distribution, Estuarine fishes, Resource partitioning, Shallow water.

\section{Introduction}

Fishes of the family Gerreidae, commonly known as mojarras, are one of the most abundant groups of fishes inhabiting nearshore waters in the tropics and subtropics worldwide (Nelson, 2006). Mojarras represent an important marine resource for commercial and artisanal fisheries, particularly on the Brazilian coast (Figueiredo \& Menezes, 1980). The mojarras are mainly benthivorous fishes with a tubelike, protrusible mouth, which they can extend downward when protracted to feed efficiently on soft and sandy substrates and to prey on benthic invertebrates near or on the bottom (Arenas-Granados \& Acero P., 1992; Nelson, 2006).

Six species of mojarras, Diapterus rhombeus (Cuvier, 1929), Eugerres brasilianus (Cuvier, 1830), Eucinostomus melanopterus (Bleeker, 1863), Eucinostomus gula (Quoy \& Gaimard, 1824), Eucinostomus argenteus Girard \& Baird, 1855 and Ulaema lefroyi (Goode, 1874), are found along the rio Mamanguape estuary (Xavier et al., 2012; Oliveira \&

${ }^{1}$ Universidade Federal da Paraíba, Departamento de Sistemática e Ecologia, Cidade Universitária, 8051-900 João Pessoa, PB, Brazil. (ALFA) limeirafelinto@gmail.com (corresponding author)

${ }^{2}$ Laboratório de Ecologia de Peixes, Departamento de Biologia, Universidade Estadual da Paraíba, Bodocongó, 58429-500 Campina Grande, PB, Brazil. (RPD) renatopdantas@gmail.com, (ALMP) andrepessanhauepb@gmail.com 
Pessanha, 2014). Three species are dominant, ranking as the most abundant species in both numbers and biomass: D. rhombeus, E. melanopterus and E. brasilianus. Juveniles of mojarra species sometimes occur at high densities in tropical and subtropical estuaries (Tapia-García \& AyalaPérez, 1996, 1997; Araújo \& Santos, 1999; Barletta \& Blaber, 2007; Barletta \& Costa, 2009), and use this habitat as a nursery ground, mainly due to high food availability and low predation pressure. The highest densities of juveniles of mojarra have been recorded in shallow, warmer and low salinity areas and where the sediment consisted of a high proportion of medium and fine sand where polychaetes were abundant (Pessanha \& Araújo, 2014). Moving into shallow water confers specific fitness benefits on mojarras, such as the ability to exploit temporally and spatially dynamic nursery grounds, which may change the ratio of mortality risk to growth rate (Cyrus \& Blaber, 1983). The wide salt tolerance of mojarras has also been highlighted as an important characteristic for their success in euryhaline estuarine and marine environments (Kerschner et al., 1985).

In natural populations, competition over evolutionary time leads to niche differentiation, principally among cofamiliars, which acts to minimise competition (Platell \& Potter, 2001). A common approach is partitioning models between coexisting species, particularly regarding spatiotemporal and ontogenetic dietary shifts in resource sharing (Pessanha \& Araújo, 2014). To understanding the role of feeding ecology for fish species, it is important to know how they use food resources throughout their life cycle. Previous studies on the feeding ecology of juvenile mojarras have reported that their most important preys are polychaetes and microcrustaceans (Teixeira \& Helmer, 1997; Bouchereau \& Chantrel, 2009; Pessanha \& Araújo, 2014).

In estuarine areas, the selection of microhabitats is usually considered a strategy of closely related species, developed through evolution, to encourage the exploitation of resources (Ricklefs, 2003). The shallow areas are primarily habitats for the mojarras juveniles. The pattern observed particularly involves movement of fishes from protected and shallow habitats (e.g. mangroves, seagrass or macroalgal beds) to open habitats in adjacent coastal areas or deeper sites $(>1.5 \mathrm{~m})$. These shifts in habitats by Gerreidae have been examined in estuaries (Barletta \& Blaber, 2007; Gning et al., 2010; Ramos et al., 2014), coastal lagoons (Arenas-Granados \& Acero P., 1992; Branco et al., 1997) and tropical and subtropical bays (Chaves \& Robert, 2001; Pessanha \& Araújo, 2012).

Given the morphological and ecological similarities between mojarra co-familiars, this study aimed to investigate distribution, abundance and feeding ecology of three sympatric mojarras in a tropical estuary, to answer the following questions: (i) What abiotic factors influence the abundance and distribution of these species in an estuarine environment? (ii) Are the species partitioning the estuarine habitat? (iii) To what degree do mojarras partition food resources in different habitats in this tropical estuary?

\section{Materials and Methods}

Study Area. The rio Mamanguape estuary is located on the north coast of the Paraíba State and extends for 25 $\mathrm{km}$ in the east-west direction and for $5 \mathrm{~km}$ in the northsouth direction. It is part of the Environmental Protection Area (Área de Proteção Ambiental - APA) of Barra de Mamanguape (Fig. 1). The regional climate is classified by Köppen as As-type (hot and humid). The rainy season begins in February and lasts until July, with maximum rainfalls occurring from April to June, whereas the dry season occurs in the spring and summer, with the lowest rainfalls occurring between October and December. The average rainfall recorded in the area is between 1,750 and $2,000 \mathrm{~mm}$ annually, and the average temperature is approximately $24-26^{\circ} \mathrm{C}$. There is a well-preserved mangrove forest in the area, composed of Avicennia germinans L., Avicennia schaueriana Stapf \& Leechman, Conocarpus erectus L., Laguncularia racemosa Gaertn and Rhizophora mangle L., which grows around the main channel and tidal creek and extends to 600 ha, in addition to Atlantic Forest remnants (Rocha et al., 2008). Endangered species, such as the seahorse, Hippocampus reidi Ginsburg, and the West Indian manatee, Trichechus manatus L., are also found in this estuary (Mourão \& Nordi, 2003).

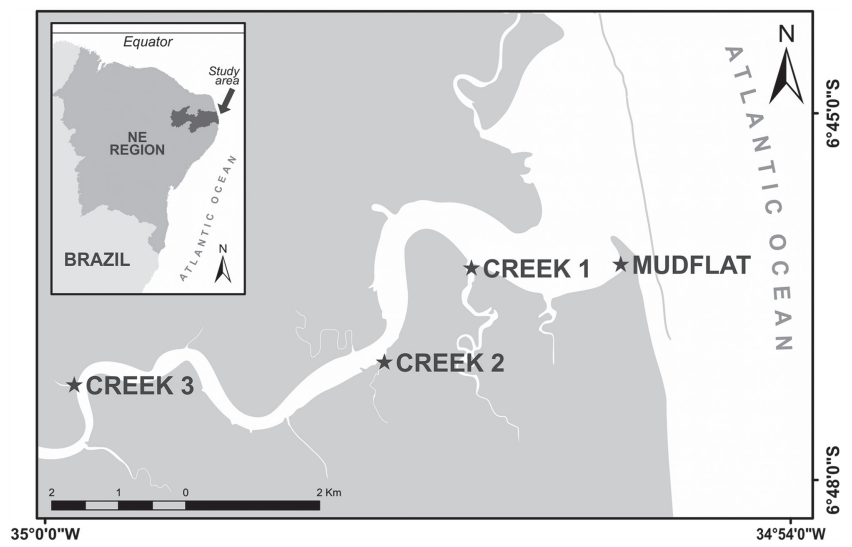

Fig. 1. Map of the study area with locations of the sampling sites in the rio Mamanguape Estuary, Brazil: 1- Mud flat; 2Tidal Creek 1; 3- Tidal Creek 2; 4- Tidal Creek 3.

Four collection sites were established along an estuarine salinity gradient and distinct physiographic features (Fig. 1): (1) Mudflat: unvegetated tidal bottoms and found in protected estuaries characterized by lower influence of waves, fine sediment (somewhat muddy), and that during low tide extend $1.22 \mathrm{~km}$, (2) Tidal Creek 1: is a mangrove channel wide and shallow $(0.72 \mathrm{~m})$, which is bordered by a mangrove forest preserve $(5.3 \mathrm{~km})$, substrate is a sandy type that forms sandbars exposed during the low tide, (3) Tidal Creek 2: is a mangrove canal located in the most central part of the estuary, bordered along its entire extension $(1.4 \mathrm{~km})$ of mangrove well preserved, deeper $(0.82 \mathrm{~m})$ and muddy 
sediment, (4) Tidal Creek 3: is a mangrove channel shallow and narrower $(0.50 \mathrm{~m})$ also bordered by mangroves along its extension $(0.62 \mathrm{~km})$, situated at the in the upper part of the estuary with muddy sediment and greater influence from continental water.

Sampling and data analysis. Samples were collected monthly in both the rainy season (January to July 2011) and the wet season (August to December 2011) to sample the ichthyofauna of the estuary over the range of the local hydrological regime. Fish were collected during daylight using a beach seine $(10 \mathrm{~m}$ long and $1.5 \mathrm{~m}$ height, with a stretched mesh size of $5 \mathrm{~mm}$ ) which was hauled parallel to an extension of approximately $30 \mathrm{~m}$ and to a maximum depth of $1.5 \mathrm{~m}$. All individuals caught were juveniles (Ramos et al., 2014) and were fixed in 10\% formalin for later identification in the laboratory. The total length (TL, mm) of each individual were measured. Fish were dissected and all prey in stomachs identified under a stereomicroscope to the lowest possible taxonomic level.

Temperature, salinity, and water transparency were measured using a thermometer, an optical refractometer, and a Secchi disc, respectively. The sampling unit was standardised with five replicates in an effort to capture individuals that use the area for feeding. In each site, two sampling were collected using a polyethylene corer with an inside diameter of $7 \mathrm{~cm}$ at a depth of $15 \mathrm{~cm}$. Samples were collected at intertidal areas during low tide. The sediment organic matter content was quantified by the weight difference between sediment's weight after oven drying at $60^{\circ} \mathrm{C}$ for $72 \mathrm{~h}$, and the sediment's weight after combustion at $500^{\circ} \mathrm{C}$ for $8 \mathrm{~h}$, and then expressed as a percentage of total sample weight. Grain size analysis was carried out by mechanical separation through a column of sieves with different mesh sizes. The following Brown \& McLachlan (1990) classification system was used: very coarse sand $>$ $2.000 \mathrm{~mm}$; coarse sand $>2.000 \mathrm{~mm}-<0.500 \mathrm{~mm}$, medium sand $>0.250-<0.500 \mathrm{~mm}$, fine sand $>0.125-<0.250 \mathrm{~mm}$, silt $>0.038-<0.125 \mathrm{~mm}$ and clay $<0.038 \mathrm{~mm}$, and the different fractions expressed as a percentage of the total sample's weight.

To analyse the diet of each individual, the frequency of the volume $(\% \mathrm{~V})$ of different food items were measured. Volumes of each items were made in a way similar to that of Bemvenuti (1990) and analyzed by displacement methods. The separate items were evenly compressed between two glass plates and volume recorded on a Petri dish with a 100 grid points. Prey items and fragments falling upon each of the 100 grid points were counted and volume was recorded. Total volumes of each item were obtained by summing individual volumes across all samples. Volumetric proportion of each item was then calculated on the basis of the total volume of food eaten per consumer. Although the volumes of both unidentifiable materials were also calculated, these were not considered valid dietary categories and were not included in subsequent dietary analysis.
Two-way analysis of variance (with significance level set at $\mathrm{P}<0.05$ ) was used to compare fish abundance (catch per unit effort - CPUE) and environmental variables between seasons and among sites. All biotic and environmental data were previously log transformed using $\log 10(\mathrm{x} 1)$, where $\mathrm{x}$ is the raw value, to address the assumptions of normality and homogeneity of variance of the parametric analyses. A post-hoc Tukey's HSD test followed ANOVA procedures every time the null hypothesis was rejected at $\alpha=0.05$ (Zar, 2010). In addition, the Spearman correlation coefficient was used to determine the significance of relationships between environmental variables and fish abundance (Zar, 2010).

Environmental variables were normalized and examined using principal component analysis (PCA). PCA used environmental and granulometric data to summarise and describe relationships among variables and to detect patterns along the estuary. Non-metric multidimensional scaling (nMDS) ordination of the volume of food items was applied to represent trophic groups graphically. A matrix of food items was constructed to reduce the number of samples to facilitate the detection of feeding patterns, as described by Schafer et al. (2002) and Platell \& Potter (2001). Each individual of the three mojorra species had often consumed only a small number of the 32 dietary categories. This mean that the dietary data for a single individual contained large numbers of zero values, giving rise to instabilities in the calculation of similarities at an individual level, which greatly reduced the effectiveness of multivariate analyses of dietary data. This problem was efficiently minimised by averaging the dietary data $(\% \mathrm{~V})$ for pooling stomachs contents of 3 to 5 individuals to produce a new series of replicates for a given factor (i.e. species or season within species). The Bray-Curtis coefficient was calculated and after a fourthroot transformation, one-way analysis of similarity (ANOSIM) was performed on the similarity matrix to test whether the composition of the diet differed significantly among the mojarra species. Similarity percentages (SIMPER) were used to determine which dietary items contributed most to similarity between the samples for different mojarra species. The multivariate analyses were performed with the PRIMER software package, version 6.0 (Clarke, 1993).

The Shannon-Wiener diversity index using a natural logarithm (Krebs, 1989), which corresponds to dietary breadth, was calculated for each species using the volumetric data of feeding.

\section{Results}

Environmental data. Environmental data on temperature, salinity and transparency are presented in Table 1 . There were no differences in temperature among sites and seasons (Table 2). Salinity and transparency were different between sites and seasons (Tukey test: $\mathrm{P}<0.01$; Table 2). 
The highest salinity and water transparency were record in Mudflat and Tidal Creek 1 (Tukey test: $\mathrm{P}<0.01$ ) and the highest values were recorded during the dry season.

Substratum differed among habitats: Mudflat and Tidal Creek 1 had substrata dominated by coarse and medium sand ( $>91 \%$ and $>84 \%$, respectively) and also had higher levels of organic matter than other sites (Mudflat $=3.47 \%$ and Tidal Creek $1=4.19 \%$ ); Tidal Creek 2 and Tidal Creek 3 substrata were characterised by fine and medium sand, and low levels of organic matter (3.6\% and $1.87 \%$, respectively).

Principal components (PC1, PC2 and PC3) explained $84.4 \%$ of the variation in abiotic factors; the first component (PC1) explained $51.2 \%$, the second component (PC2) explained $20.5 \%$ and the third axis (PC3) explained $12.7 \%$ of the variation (Fig. 2). High scores on PC1 were associated with fine sand and organic matter, whereas low scores were associated with temperature and clay (Table $3)$. High scores on PC2 were associated with clay and medium sand, whereas low scores were associated with temperature and salinity (Table 3). High scores on PC3 were associated with transparency, whereas low scores were associated with temperature and salinity (Table 3). A combination of these variables along the Principal Component axes allowed identification of important features for distinct estuary areas, with indications of an environmental gradient along the estuary (Fig. 2): this division of sites suggests that first PC1 and PC2 axis represent a sediment gradient in estuary, whereas that the third PC3 axis represent a temperature and salinity gradient. The recognized gradient demonstrated that in sites with more positive scores on the first and third axes were plotted to the left part of the diagram (Tidal Creek 2 and 3), whereas sites with negative scores (Mudflat and Tidal Creek 1) lay to the other extreme in the PCA diagram.
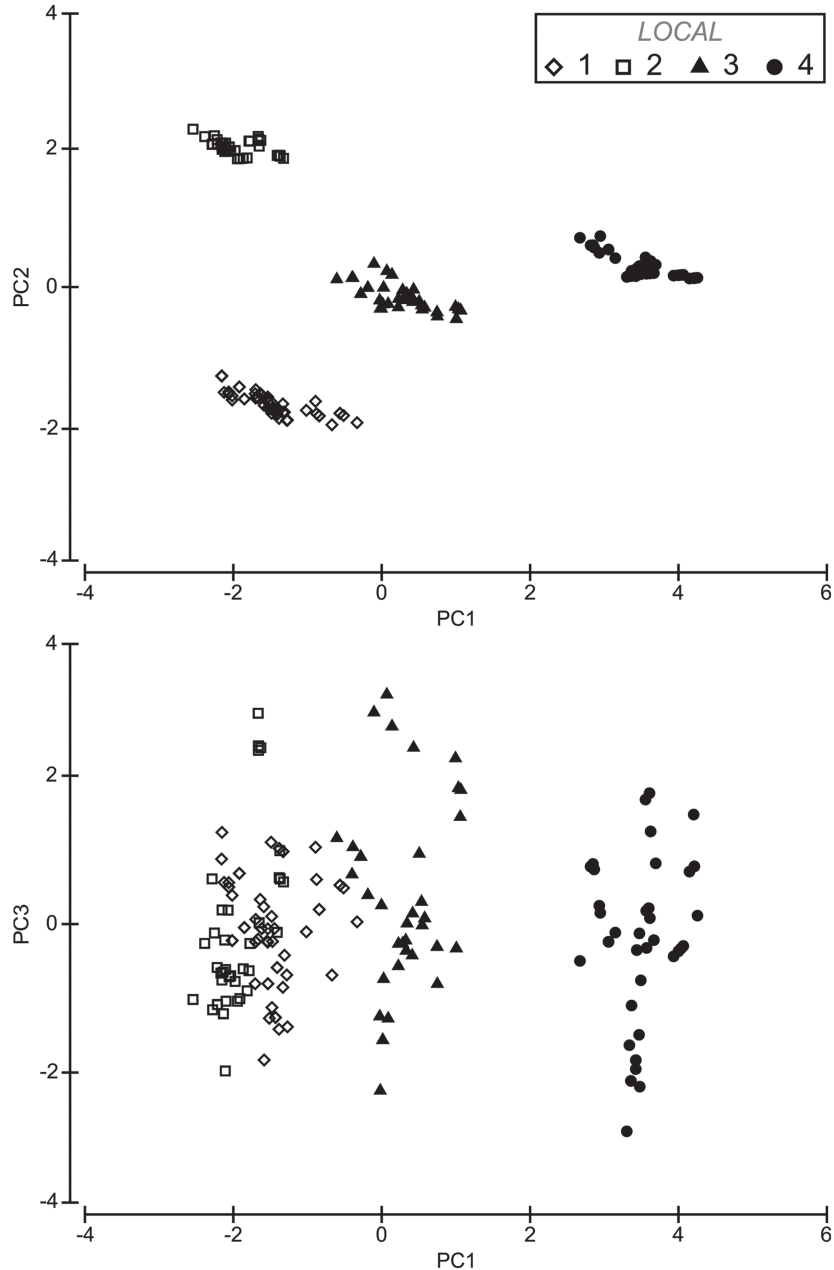

Fig. 2. Ordination Diagram for principal components analysis on environmental parameters $(\mathrm{A}=\mathrm{PC} 1$ vs. $\mathrm{PC} 2 ; \mathrm{B}=$ PC1 vs. PC3), coded by site from rio Mamanguape estuary. Sites: Mud flat (Diamond); Tidal Creek 1 (Square); Tidal Creek 2 (Black triangle); Tidal Creek 3 (Black dot).

Table 1. Mean variations in the environmental parameters $( \pm \mathrm{SE})$ for the study period in rio Mamanguape estuary, northeastern Brazil.

\begin{tabular}{|c|c|c|c|c|c|c|}
\hline \multirow{2}{*}{ Environmental parameters } & \multicolumn{2}{|c|}{ Temperature } & \multicolumn{2}{|c|}{ Salinity } & \multicolumn{2}{|c|}{ Transparency } \\
\hline & Wet & Dry & Wet & Dry & Wet & Dry \\
\hline Mudflat & $29.0 \pm 0.3$ & $29.6 \pm 0.3$ & $24.4 \pm 1.3$ & $34.9 \pm 0.6$ & $37.1 \pm 2.6$ & $44.6 \pm 3.0$ \\
\hline Tidal Creek1 & $30.0 \pm 0.3$ & $29.3 \pm 0.6$ & $26.8 \pm 1.5$ & $31.3 \pm 1.3$ & $50.6 \pm 2.3$ & $56.6 \pm 1.6$ \\
\hline Tidal Creek2 & $29.9 \pm 0.6$ & $28.9 \pm 0.5$ & $17.2 \pm 2.0$ & $16.9 \pm 1.5$ & $33.3 \pm 3.9$ & $46.0 \pm 3.4$ \\
\hline Tidal Creek3 & $29.9 \pm 0.5$ & $28.7 \pm 0.5$ & $13.2 \pm 1.8$ & $17.0 \pm 0.8$ & $7.7 \pm 1.7$ & $53.7 \pm 5.1$ \\
\hline
\end{tabular}

Table 2. F-values from two-way analysis of variance and comparisons (Tukey test) for environmental parameters in rio Mamanguape estuary, northeastern Brazil.

\begin{tabular}{|c|c|c|c|c|c|c|c|c|c|c|}
\hline \multirow[b]{2}{*}{ Factors } & \multirow[b]{2}{*}{ df } & \multicolumn{3}{|c|}{ Temperature } & \multicolumn{3}{|c|}{ Salinity } & \multicolumn{3}{|c|}{ Transparency } \\
\hline & & MS & $\mathrm{F}$ & $\mathrm{P}$ & MS & $\mathrm{F}$ & $\mathrm{p}$ & MS & $\mathrm{F}$ & $\mathrm{p}$ \\
\hline Sites (L) & 1 & 0.000 & 0.132 & 0.941 & 1.361 & 46.221 & 0.000 & 3.739 & 71.973 & 0.000 \\
\hline Seasons (S) & 3 & 0.004 & 2.987 & 0.086 & 0.529 & 17.971 & 0.000 & 3.014 & 58.009 & 0.000 \\
\hline (L) x (S) & 3 & 0.002 & 1.510 & 0.213 & 0.053 & 1.816 & 0.146 & 0.805 & 15.504 & 0.000 \\
\hline Error & 185 & 0.001 & & & 0.029 & & & 0.052 & & \\
\hline
\end{tabular}


Table 3. Factors loads from principal component analysis on environmental parameters from rio Mamanguape estuary, northeastern Brazil.

\begin{tabular}{lccc}
\hline Factor loads & PC 1 & PC2 & PC3 \\
\hline Temperature $\left({ }^{\circ} \mathrm{C}\right)$ & -0.029 & -0.001 & -0.890 \\
Salinity & -0.328 & -0.027 & -0.351 \\
Transparency $(\mathrm{cm})$ & -0.319 & 0.194 & 0.248 \\
Clay $(\mathrm{g})$ & -0.216 & 0.595 & 0.043 \\
Silt $(\mathrm{g})$ & 0.397 & 0.371 & -0.056 \\
Fine sand $(\mathrm{g})$ & 0.445 & 0.134 & -0.003 \\
Medium sand $(\mathrm{g})$ & -0.273 & -0.571 & 0.088 \\
Coarse sand $(\mathrm{g})$ & -0.363 & 0.321 & -0.074 \\
Organic Matter $(\mathrm{g})$ & -0.426 & 0.152 & 0.073 \\
Eigenvalues & $\mathbf{4 . 6 1}$ & $\mathbf{1 . 8 4}$ & $\mathbf{1 . 1 4}$ \\
Explained Variance $(\%)$ & $\mathbf{5 1 . 2}$ & $\mathbf{2 0 . 5}$ & $\mathbf{1 2 . 7}$ \\
\hline
\end{tabular}

Distribution and abundance. Juveniles of Diapterus rhombeus (92 individuals; Size range: 14-115 mm TL), Eucinostomus melanopterus (216 individuals; Size range: 8-74 mm TL) and Eugerres brasilianus (322 individuals; Size range: 18-99 $\mathrm{mm}$ TL) were captured at all sampling sites. Abundance differed significantly among sites for species (Table 4; Fig. 3). Overall, the highest abundance of juvenile mojarras was recorded in the upper estuary, mainly in Tidal Creek 2 and Tidal Creek 3. The greatest abundance was recorded during the rainy season throughout the estuary for all mojarra species. However, only $D$. rhombeus and $E$. melanopterus differed significantly in abundance (Table 4; Fig. 3).

The nonparametric Spearman coefficient showed that abundance of E. melanopterus was positively correlated with salinity $\left(r_{\mathrm{s}}=0.31 ; \mathrm{P}<0.01\right)$ and transparency $\left(\mathrm{r}_{\mathrm{s}}=0.24\right.$; $\mathrm{P}<0.01$ ), while E. brasilianus was negatively correlated with salinity $\left(\mathrm{r}_{\mathrm{s}}=-0.20 ; \mathrm{P}<0.01\right)$ and positively correlated with temperature $\left(\mathrm{r}_{\mathrm{s}}=0.17 ; \mathrm{P}<0.01\right)$. Occurrence of $D$. rhombeus abundance was not correlated with any measured environmental variables.

Diet composition. A total of 630 stomachs were analysed and the dominant prey were zooplankton and some infauna (Table 5). Calanoida and Cyclopoida dominated the diets of mojarras. These two items contributed $21-42 \%$ of the volume three mojarra species. Although infauna items were ingested by all three species, their volumetric contributions to the diets were small. Sand was occasionally found in the stomachs of mojarra species (Table 5). SIMPER showed that $D$. rhombeus and E. melanopterus consumed relatively greater volumes of Calanoida and Cyclopida, whereas the diet of E. brasilianus was distinguished by relatively lower proportions of copepods and larger contributions of infauna. The others items contributed for species diet were Nematoda (D. rhombeus and E. brasilianus); Diatoms, Ostracoda and Bivalvia (E. melanopterus); Polychaeta, Decapoda, foraminifera and plant material (E. brasilianus) (Table 6).
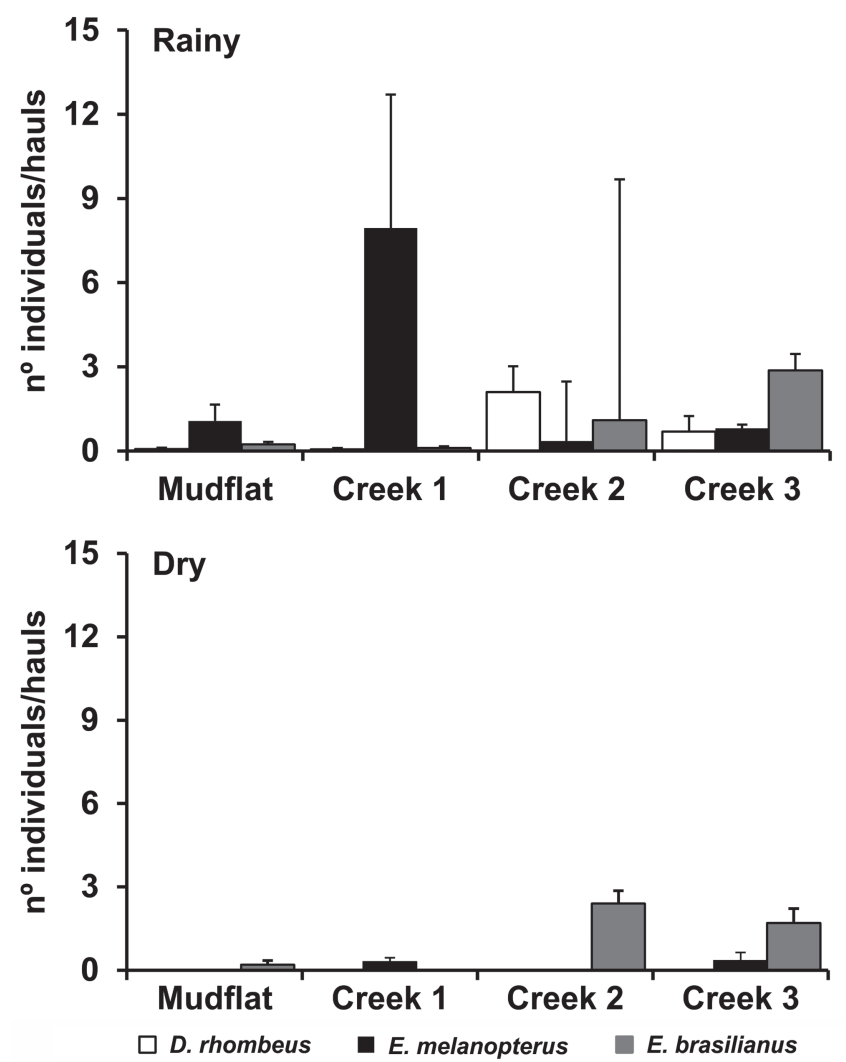

Fig. 3. Spatial variation of numerical abundance of the three species (Diapterus rhombeus, Eucinostomus melanopterus and Eugerres brasilianus) in the rio Mamanguape estuary, Brazil.

Table 4. F-values from two-way analysis of variance and comparisons (Tukey test) for numerical abundance (CPUE) for the three species between sites in the rio Mamanguape estuary, northeastern Brazil.

\begin{tabular}{|c|c|c|c|c|c|c|c|c|c|c|}
\hline CPUE & & \multicolumn{3}{|c|}{ Diapterus rhombeus } & \multicolumn{3}{|c|}{ Eucinostomus melanopterus } & \multicolumn{3}{|c|}{ Eugerres brasilianus } \\
\hline Factors & df & MS & $\mathrm{F}$ & $\mathrm{p}$ & MS & $\mathrm{F}$ & $\mathrm{p}$ & MS & $\mathrm{F}$ & $\mathrm{p}$ \\
\hline Sites (L) & 3 & 0.386 & 14.245 & 0.000 & 0.270 & 3.35 & 0.020 & 1.879 & 20.632 & 0.000 \\
\hline Seasons (S) & 1 & 1.376 & 50.787 & 0.000 & 1.961 & 24.41 & 0.000 & 0.002 & 0.017 & 0.895 \\
\hline$(\mathrm{L}) \times(\mathrm{S})$ & 3 & 0.386 & 14.245 & 0.000 & 0.176 & 2.19 & 0.091 & 0.079 & 0.865 & 0.460 \\
\hline Error & 202 & 0.027 & & & 0.080 & & & 0.091 & & \\
\hline
\end{tabular}


Table 5. Percentage volume $(\% \mathrm{~V})$ values of feeding items used by Diapterus rhombeus (Dr), Eucinostomus melanopterus $(\mathrm{Em})$ and Eugerres brasilianus $(\mathrm{Eb})$ in each site of the rio Mamanguape estuary, northeastern Brazil. $\mathrm{n}=$ number of individuals.

\begin{tabular}{|c|c|c|c|c|c|c|c|c|c|c|c|}
\hline \multirow[b]{2}{*}{ Food items } & \multicolumn{3}{|c|}{ Mudflat } & \multicolumn{2}{|c|}{ Tidal Creek 1} & \multicolumn{3}{|c|}{ Tidal Creek 2} & \multicolumn{3}{|c|}{ Tidal Creek 3} \\
\hline & $\begin{array}{c}\mathrm{Dr} \\
\mathrm{n}=3\end{array}$ & $\begin{array}{c}\mathrm{Em} \\
\mathrm{n}=33\end{array}$ & $\begin{array}{c}E b \\
n=15\end{array}$ & $\begin{array}{c}\mathrm{Dr} \\
\mathrm{n}=1\end{array}$ & $\begin{array}{c}E m \\
\mathrm{n}=112\end{array}$ & $\begin{array}{c}\text { Dr } \\
\mathrm{n}=39\end{array}$ & $\begin{array}{c}E m \\
\mathrm{n}=56\end{array}$ & $\begin{array}{c}\mathrm{Eb} \\
\mathrm{n}=250\end{array}$ & $\begin{array}{c}\text { Dr } \\
\mathrm{n}=49\end{array}$ & $\begin{array}{c}\mathrm{Em} \\
\mathrm{n}=15\end{array}$ & $\begin{array}{c}\mathrm{Eb} \\
\mathrm{n}=57\end{array}$ \\
\hline Cyclopoida & 22.9 & 72.3 & 13.1 & - & 33.4 & 32.2 & 18.4 & 34.6 & 49.5 & 53.0 & 44.0 \\
\hline Calanoida & 15.3 & 18.8 & 31.3 & - & 22.8 & 36.2 & 52.4 & 34.2 & 16.5 & 13.2 & 26.2 \\
\hline Ostracoda & 30.6 & - & 1.0 & - & 13.1 & 0.6 & 0.7 & 0.2 & 5.5 & 1.8 & 0.2 \\
\hline Amphipoda & - & - & - & - & - & - & - & 0.4 & 0.4 & - & - \\
\hline Harpacticoida & - & 2.2 & 9.6 & - & - & - & - & - & 0.9 & - & - \\
\hline Isopoda & - & - & - & - & - & - & 4.6 & 0.5 & 1.3 & 1.2 & 2.9 \\
\hline Decapoda & - & - & - & - & - & 3.4 & - & 4.4 & 0.4 & 0.6 & - \\
\hline Other crustaceans & - & - & 0.3 & - & 2.0 & - & 0.6 & 0.5 & - & - & 2.9 \\
\hline Polychaeta & 3.8 & - & 5.2 & - & 0.6 & 15.8 & 14.7 & 18.7 & 3.2 & 12.7 & 14.0 \\
\hline Nematoda & 11.4 & 2.2 & 24.1 & - & 0.6 & 4.1 & 1.5 & 1.0 & 7.7 & 0.6 & 2.6 \\
\hline Fish & - & - & - & - & 1.2 & 4.1 & 11.4 & 0.3 & 2.6 & 11.4 & - \\
\hline Gastropoda & - & - & 0.3 & - & 1.6 & - & - & 0.5 & 0.4 & - & - \\
\hline Bivalvia & - & 1.1 & - & - & 24.2 & - & - & - & - & 0.6 & 0.7 \\
\hline Invertebrate egg & - & - & 1.0 & - & 1.3 & 0.6 & 0.7 & 0.3 & 1.3 & 0.8 & - \\
\hline Diptera & - & - & - & - & - & - & 0.7 & 0.4 & 0.9 & 0.6 & - \\
\hline Algae & 7.6 & 2.2 & 11.6 & 95.2 & 1.1 & 1.3 & - & 0.4 & 2.7 & - & - \\
\hline Plant material & - & 1.1 & 1.3 & - & - & - & 2.4 & 2.4 & 1.3 & 0.6 & 4.6 \\
\hline Foraminifera & 7.6 & - & - & - & 2.6 & 0.6 & 2.3 & 1.2 & 1.8 & 0.6 & 1.7 \\
\hline Diatoms & - & 2.1 & - & - & 0.6 & $<0.1$ & $<0.1$ & $<0.1$ & - & 0.1 & - \\
\hline
\end{tabular}

Table 6. Similarity values and Contribution (\%) obtained by the SIMPER analysis for percentage volume values of feeding items used by Diapterus rhombeus, Eucinostomus melanopterus and Eugerres brasilianus in the rio Mamanguape estuary, northeastern Brazil.

\begin{tabular}{|c|c|c|c|c|c|c|}
\hline \multirow[b]{2}{*}{ Items } & \multicolumn{2}{|c|}{$\begin{array}{c}\text { D. rhombeus } \\
\text { Similarity }=60.95\end{array}$} & \multicolumn{2}{|c|}{$\begin{array}{c}\text { E. melanopterus } \\
\text { Similarity }=57.67\end{array}$} & \multicolumn{2}{|c|}{$\begin{array}{c}\text { E. brasilianus } \\
\text { Similarity }=76.65\end{array}$} \\
\hline & $\begin{array}{c}\text { Contribution } \\
(\%)\end{array}$ & $\begin{array}{l}\text { Cumulative } \\
\text { Contribution }\end{array}$ & $\begin{array}{c}\text { Contribution } \\
(\%)\end{array}$ & $\begin{array}{l}\text { Cumulative } \\
\text { Contribution }\end{array}$ & $\begin{array}{c}\text { Contribution } \\
(\%)\end{array}$ & $\begin{array}{l}\text { Cumulative } \\
\text { Contribution }\end{array}$ \\
\hline Cyclopoida & 45.04 & 45.04 & 42.71 & 42.71 & 23.23 & 23.23 \\
\hline Calanoida & 32.11 & 77.15 & 19.88 & 62.58 & 22.85 & 46.08 \\
\hline Nematoda & 13.30 & 90.44 & - & - & 7.17 & 53.25 \\
\hline Diatoms & - & - & 13.04 & 75.62 & - & - \\
\hline Ostracoda & - & - & 10.27 & 85.89 & - & - \\
\hline Bivalvia & - & - & 8.75 & 94.64 & - & - \\
\hline Polychaeta & - & - & - & - & 13.86 & 67.11 \\
\hline Decapoda Larvae & - & - & - & - & 10.52 & 77.63 \\
\hline Foraminifera & - & - & - & - & 6.74 & 84.37 \\
\hline Plant material & - & - & - & - & 6.45 & 90.82 \\
\hline
\end{tabular}

Spatial changes in diet were observed between habitats (Table 5). In mudflat, Cyclopoida and Calanoida was the most common food item for all mojarras, with Ostracoda showing second importance for $D$. rhombeus and Nematoda for $E$. brasilianus. In Tidal Creek 1, a large amount of Algae was the main item in diet to D. rhombeus, whereas to $E$. melanopterus, Calanoida and Cycloida were the main items. In Tidal Creek 2 and Tidal Creek 3, diet of all mojarras was based Calanoida, Cycloida and Polychaeta. The dietary composition differed significantly among the three mojarra species between habitats (ANOSIM; Global $\mathrm{R}=0.560$; $\mathrm{P}=0.01$; Fig. 4). When the mean percentage volumetric contributions of the different dietary categories in each dietary sample of the mojarras species were subject to ordination, the nMDS plot showed separation among species and habitats. While E. brasilianus lay to the left part of the diagram due to their similar diets, the samples from E. melanopterus, that showed preference for other food items, lay to the right side of the diagram (Fig. 4). The dietary samples of the $D$. rhombeus lay to the middle part of the diagram (Fig. 4). 
Niche breadth values of the three sympatric mojarras were calculated, with higher values for $E$. brasilianus and D. rhombeus $\left(\mathrm{H}^{\prime}=0.28\right.$ and $\mathrm{H}^{\prime}=0.24$, respectively), while E. melanopterus demonstrated lower values $\left(\mathrm{H}^{\prime}=0.13\right)$.

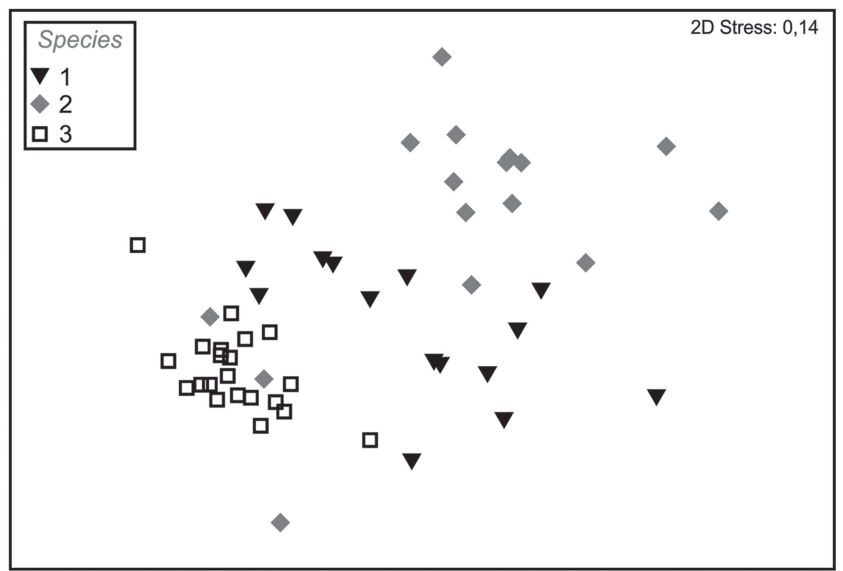

Fig. 4. Non-metric multidimensional scaling plots (nMDS) coded by habitat for Diapterus rhombeus, Eucinostomus melanopterus and Eugerres brasilianus in the rio Mamanguape estuary, Brazil. Filled symbols (gray $=D$. rhombeus and black= E. melanopterus) and open symbols (E. brasilianus).

\section{Discussion}

This study demonstrates spatial partitioning among juvenile mojarras. This strategy, in response to the sediment, temperature and salinity gradient and physical processes such as seasonal hydrology and distance from the estuary mouth, allows the three species to coexist in this estuary: Eucinostomus melanopterus was associated with downstream sites with higher salinity and sand substrate, whereas Eugerres brasilianus was more abundant at upstream sites with lower salinity, higher temperature and muddy substrate. Thus, salinity may be an important factor that driving the abundance of mojarras in estuary, and their occurrence may be altered in response to salt tolerance. This spatial separation is critical to the maintenance of mojarra populations, because different habitats influence abundance, growth, reproduction, recruitment and survival (Hajisamae et al., 2006). Similar spatial dynamics were reported for gerreids in tropical estuaries by Franco et al. (2012) and Ramos et al. (2014). Several studies in tropical areas have reported intrinsic changes in habitat preferences by juvenile fishes in response to local prey availability, predation risk and abiotic conditions (Gibson et al., 1998; Martino \& Able, 2003; Johnston et al., 2007; Costa et al., 2012).

Spatial segregation of juveniles conditioned by salinity assumes that niche filtering limits the distributions of populations at a local scale (abiotic properties of the habitat) (Mouillot et al., 2007; Planqué et al., 2011). Salinity has been identified as an important influence on choice of nursery areas in other estuarine fish species (Gning et al., 2010). These choices often depend on additional factors such as availability of foraging or other necessary resources in a particular area, or avoidance of physiological stress and enemies (Planqué et al., 2011). Castillo-Rivera et al. (2005) found that in the early life stages, mojarras tolerate low salinity in a tropical coastal lagoon; other authors have suggested that salinity can function as a selective filter due to effects on osmoregulatory capacity, preventing species from moving very far up the estuary (Teixeira \& Helmer, 1997; Costa et al., 2012; Passos et al., 2013). Both Barletta et al. (2005) and Ramos et al. (2014) have shown that movement across habitats by mojarras in tropical estuaries may be a response to physicochemical environmental conditions.

Patterns of abundance of mojarras recorded in this estuary revealed a relationship between recruitment and the wet season: for E. brasilianus a larger number of juveniles was recorded during the early wet season (December to March), whereas juvenile E. melanopterus were mainly found in the late wet season (May to July). Thus, was hypothesised that low abundance during the dry season was because mojarra larvae avoided the highest salinity waters $(>25)$, with a strong influence on seasonal recruitment of these species. The hypothesis is supported because fish often have higher growth rates in intermediary salinity conditions (between 8 and 20) (Boeuf \& Payan, 2001). The distribution and abundance of juvenile mojarras in shallow waters were found to be positively correlated with rainfall, salinity regimen and productivity (Teixeira \& Helmer, 1997; Chaves \& Robert, 2001; Castillo-Rivera et al., 2005). Several mojarra species start reproduction during the period of highest rainfall, such as E. melanopterus (Chaves \& Robert, 2001) and D. rhombeus (Costa et al., 2012). However, $E$. argenteus showed a wide period of recruitment in a tropical bay suggesting a long spawning period (Araújo \& Santos, 1999). Elsewhere in tropical coastal Brazil, three common catfishes (Cathorops spixii Agassiz, C. agassizii Eigenmann \& Eigenmann and Sciades herzbergii Bloch) and sciaenid species (Steliffer brasiliensis Schultz and $S$. steliffer Bloch) peaked in juvenile abundance during the rainy season, a reflection of reproductive cycles (Dantas et al., 2010, 2015), a pattern similar to our findings.

According to our results, there was a high contribution to the diet of planktonic prey groups (especially Cyclopoida and Calanoida), instead of a variety of benthic invertebrates. Overall individuals captured in this study were juveniles, and zooplankton is known to be a highly important food item at this stage. Studies in tropical estuaries (Teixeira \& Helmer, 1997; Ramos et al., 2014), mangroves (Kerschner et al., 1985), mudflats (Pessanha \& Araújo, 2014) and tropical bays (Pessanha \& Araújo, 2012) have found high volumes of zooplankton prey in the stomach of juveniles of mojarra. Other authors have also reported an increasing contribution of infauna to the diet with increasing size of 
mojarra species due to nutritional requirements change during ontogeny in nursery areas (Carr \& Adams, 1973; Bouchereau \& Chantrel, 2009; Gning et al., 2010; Denadai et al., 2012).

Indications of food partitioning were found when comparing species in each habitat at one time, due to differences in volumetric proportions of the same items. For instance, at the mudflat site, the largest component of E. melanopterus diet was Cyclopoida, whereas $E$. brasilianus fed predominantly on Calanoida; in Tidal Creek 2 juvenile $D$. rhombeus fed mainly on Cyclopoida, whereas for E. melanopterus the principal prey was Calanoida. Resource partitioning and dietary plasticity is common for most generalist predators, and can mitigate competitive interactions among species for resources (Smith et al., 2011), and this is partly confirmed by our results.

This study did not address the issue of ontogenetic diet because the size of fishes retained was very similar, probably due to the sample method. The results show particularly high abundance of juveniles in mangrove fringe areas within tidal creeks. This suggests that in the riio Mamanguape estuary these areas may be an essential habitat for juvenile mojarras. Once in these habitats, mojarras often grow rapidly through a higher intake of copepods (González-Sansón \& Rodríguez-Viñas, 1983). According to Evjemo et al. (2003), several coastal copepods have a high content of both protein and fatty acids that meet the nutritional requirements of fish larvae in nursery areas. We found that larger fishes ate proportionally more of large food types such as Polychaeta. There is a well-known sizerelated shift in the diet of mojarras (Kerschner et al., 1985; Pessanha \& Araújo, 2012; Ramos et al., 2014), associated with a switch from zooplankton to polychaete feeding, which often improves growth and survival. Such changes can be seen as a strategy to reduce competition and exploit abundant resources available in the estuary (Pessanha \& Araújo, 2012).

The three mojarras investigated in this estuary behaved as trophic generalists. Other studies have compared trophic strategies of mojarras and have typically found a generalist feeding strategy (Arenas-Granados \& Acero P., 1992; Bouchereau \& Chantrel, 2009). Moreover, the marked difference in dietary compositions of mojarras observed in this study and Pessanha \& Araújo (2014) are associated with variations in the abundance of potential food items in the two habitat types: estuarine mangroves are surrounded by more simply structured habitats, such as sand habitats, whereas in mudflat in Sepetiba Bay exhibit a more complex structure. The mojarras have dietary plasticity (Denadai et al., 2012), confirming the generalist and opportunistic feeding strategies of estuarine fishes; this is consistent with the abundance and availability of prey. The distribution of prey has a strong effect on energetic gains and costs of foraging, foraging success, and overall predator performance (Smith et al., 2011). This highlights the need to supply the energy demand expended by these fish in estuaries (Bolnick et al., 2002, 2003). While balancing the cost and the benefits, predators foraging optimally can adjust their preferences to take into account prey quality rather than prey abundance (Temperoni et al., 2013).

In summary, juveniles of mojarra, despite having similar morphological characteristics, used two key mechanisms for exploitation of resources in the rio Mamanguape estuary: spatial segregation in the use of habitats along the estuarine gradient; and differences related to volume ratio of the main food items consumed. Such strategies were important for partitioning resources, favouring the coexistence of these three species in the estuary.

\section{Acknowledgements}

We thank biologists Rayssa Soares da Silva and Natalice dos Santos Sales for helping in field work and identifying feeding items. This work was partially supported by the National System of Research on Biodiversity (SISBIOTA/ BRASIL) and CNPq - Brazilian National Agency for Scientific and Technological Development (Proc. 563202/2010-6 and Proc. 477663/2011-7).

\section{References}

Araújo, F. G. \& A. C. A. Santos. 1999. Distribution and recruitment of mojarras (Perciformes, Gerreidae) in the continental margin of Sepetiba bay, Brazil. Bulletin of Marine Science, 65: 431-439.

Arenas-Granados, P. \& A. Acero P. 1992. Organización trófica de las mojarras (Pisces: Gerreidae) de la Ciénaga Grande de Santa Marta (Caribe Colombiano). Revista de Biologia Tropical, 40: 287-302.

Barletta, M., A. Barletta-Bergan, U. Saint-Paul \& G. Hubolds. 2005. The role of salinity in structuring the fish assemblages in a tropical estuary. Journal of Fish Biology, 66: 45-72.

Barletta, M. \& S. J. M. Blaber. 2007. Comparison of fish assemblages and guilds in tropical habitats of the Embley (Indo-West Pacific) and Caeté (Western Atlantic) estuaries. Bulletin of Marine Science, 80: 647-680.

Barletta, M. \& M. F. Costa. 2009. Living and non-living resources exploitation in a tropical semi-arid estuary. Journal of Coastal Research, 56: 371-375.

Bemvenuti, M. A. 1990. Hábitos alimentares de peixes-rei (Atherinidae) na região estuarina da Lagoa dos Patos. Atlântica, RS, Brasil, 12: 79-102.

Boeuf, G. \& P. Payan. 2001. How should salinity influence fish growth? Comparative Biochemistry and Physiology Part C: Toxicology \& Pharmacology, 130: 411-423.

Bolnick, D. I., R. Svanbäck, J. A. Fordyce, L. H. Yang, J. M. Davis, C. D. Hulsey \& M. L. Forister. 2003. The ecology of individuals: incidence and implications of individual specialization. American Naturalist, 161: 1-28.

Bolnick, D. I., L. H. Yang, J. A. Fordyce, J. M. Davis \& R. Svanbäck. 2002. Measuring individual - level resource specialization. Ecology, 83: 2936-2941.

Bouchereau, J-L. \& J. Chantrel. 2009. Régime alimentaire de trois gerreidés et d'un sciaenidé dans une lagune à mangrove antillaise. Cybium, 33: 179-191. 
Branco, C. W. C., T. Aguiaro, F. A. Esteves \& E. P. Caramaschi. 1997. Food sources of the teleost Eucinostomus argenteus in two coastal lagoons of Brazil. Studies on Neotropical Fauna and Environment, 32: 33-40.

Brown, A. C. \& A. McLachlan. 1990. Ecology of sandy shores. Amsterdam, New York, Elsevier, 328p.

Carr, W. E. S. \& C. A. Adams. 1973. Food habits of juvenile marine fishes occupying seagrass beds in the estuarine zone near Crystal River, Florida. Transactions of the American Fisheries Society, 102: 511-540.

Castillo-Rivera, M., M. Montiel, L. S. Añorve \& R. Zárate. 2005. Spatial, seasonal and diel distribution patterns of two species of mojarras (Pisces: Gerreidae) in a Mexican tropical coastal lagoon. Journal of Applied Ichthyology, 21: 498-503.

Chaves, P. T. C. \& M. C. Robert. 2001. Nota complementar sobre os hábitos de Gerres melanopterus (Teleostei: Gerreidae) na Baía de Guaratuba, Paraná, Brasil (25 52’S, 48³9’ W). Revista Brasileira de Zoologia, 18: 255-259.

Clarke, K. R. 1993. Non-parametric multivariate analyses of changes in community structure. Australian Journal of Ecology, 18: 117-143.

Costa, M. R., R. J. Albieri, L. M. Neves, A. B. L. Santos \& F. G. Araújo. 2012. Distribution and size of the mojarra Diapterus rhombeus (Cuvier) (Actinopterygii, Gerreidae) In a Southeastern Brazilian Bay. Brazilian Journal of Oceanography, 60: 199-207.

Cyrus, D. P. \& S. J. M. Blaber. 1983. The food and feeding ecology of Gerreidae, Bleeker 1859, in the estuaries of Natal. Journal of Fish Biology, 22: 373-393.

Dantas, D. V., M. Barletta \& M. F. Costa. 2015. Feeding ecology and seasonal diet overlap between Stellifer brasiliensis and Stellifer stellifer in a tropical estuarine ecocline. Journal of Fish Biology, 86: 707-733.

Dantas, D. V., M. Barletta, M. F. Costa, S. C. T. Barbosa-Cintra, F. E. Possatto, J. A. A. Ramos, A. R. A. Lima \& U. Saint-Paul. 2010. Movement patterns of catfishes (Ariidae) in a tropical semi-arid estuary. Journal of Fish Biology, 76: 2540-2557.

Denadai, M. R., F. B. Santos, E. Bessa, W. S. Fernandez, C. C. Paschoal \& A. Turra. 2012. Diets of Eucinostomus argenteus (Baird \& Girard, 1855) and Diapterus rhombeus (Cuvier, 1829) (Perciformes: Gerreidae) in Caraguatatuba Bay, southeastern Brazil. Pan-American Journal of Aquatic Sciences, 7: 143-155.

Evjemo, J. O., K. I. Reitan \& Y. Olsen. 2003. Copepods as live food organisms in the larval rearing of halibut larvae (Hippoglossus hippoglossus L.) whit special emphasis on the nutritional value. Aquaculture, 227: 191-210.

Figueiredo, J. L. \& Menezes, N. A. 1980. Manual de peixes marinhos do sudeste do Brasil. São Paulo, v 3: Telostei. 96 p.

Franco, T. P., L. M. Neves, T. P. Teixeira \& F. G.Araújo. 2012. Patterns of spatial distribution of five species of mojarras (Actinopterygii: Gerreidae) in a small tropical estuary in southeastern Brazil. Journal of the Marine Biological Association of the United Kingdom, 92: 1217-1225.

Gibson, R. N., L. Pihl, M. T. Burrows, J. Modin, H. Wennhage \& L. A. Nickell. 1998. Diel movements of juvenile plaice Pleuronectes platessa in relation to predators, competitors, food availability and abiotic factors on a microtidal nursery ground. Marine Ecology Progress Series, 165: 145-159.

Gning, N., F. Le Loc'h, O. T. Thiaw, C. Aliaume \& G. Vidy. 2010. Estuarine resources use by juvenile flagfin mojarra (Eucinostomus melanopterus) in an inverse tropical estuary (Sine Saloum, Senegal). Estuarine, Coastal and Shelf Science, 86: 683-691.
González-Sansón, G. \& L. Rodríguez-Viñas. 1983. Alimentacíon natural de Eugerres brasilianus (Cuvier) y Gerres cinereus (Walbaum) (Pisces: Gerreidae) en las lagunas costeras de Tunas de Zaza, Cuba. Revista de Investigaciones Marinas, 4(1): 91-134.

Hajisamae, S., P. Yeesin \& S. Chaimongkol. 2006. Habitat utilization by fishes in a shallow, semi-enclosed estuarine bay in southern Gulf of Thailand. Estuarine, Coastal and Shelf Science, 68: 647-655.

Johnston, R., M. Sheaves \& B. Molony. 2007. Are distributions of fishes in tropical estuaries influenced by turbidity over small spatial scales? Journal of Fish Biology, 71: 657-671.

Kerschner, B. A., M. S. Peterson, R. G. Gilmore, Jr. 1985. Ecotopic and ontogenetic trophic variation in mojarras (Pisces: Gerreidae). Estuaries, 8: 311-322.

Krebs, C. J. 1989. Ecological methodology. New York, HarperCollins, 654 p.

Martino, E. J. \& K. W. Able. 2003. Fish assemblages across the marine to low salinity transition zone of a temperate estuary. Estuarine, Coastal and Shelf Science, 56: 969-987.

Menezes, N. A. \& J. L. Figueiredo. 1980. Manual de peixes marinhos do sudeste do Brasil. São Paulo, v 3: Telostei. 96 p.

Mouillot, D., O. Dumay \& J. A. Tomasini. 2007. Limiting similarity, niche filtering and functional diversity in coastal lagoon fish communities. Estuarine, Coastal and Shelf Science, 71: 443456.

Mourão, J. S. \& N. Nordi. 2003. Etnoictiologia de pescadores artesanais do estuário do rio Mamanguape, Paraíba, Brasil. Boletim do Instituto de Pesca, 29: 9-17.

Nelson, J. S. 2006. Fish of the world, 4th ed. New York, J. Wiley, $601 p$.

Oliveira, R. E. M. C. C. \& A. L. M. Pessanha. 2014. Fish assemblages along a morphodynamic continuum on three tropical beaches. Neotropical Ichthyology, 12: 165-175.

Passos, A. C., R. F. Contente, F. V. Abbatepaulo, H. L. Spach, C. C. Vilar, J. C. Joyeux, B. F. C. Cartagena \& L. F. Fávaro. 2013. Analysis of fish assemblages in sectors along a salinity gradient based on species, families and functional groups. Brazilian Journal of Oceanography, 61: 251-264.

Pessanha, A. L. M. \& F. G. Araújo. 2012. Spatial and size feeding niche partitioning of the rhomboid mojarra Diapterus rhombeus (Cuvier, 1829) in a tropical Brazilian Bay. Marine Biology Research, 8: 273-283.

Pessanha, A. L. M. \& F. G. Araújo. 2014. Shifts of the feeding niche along the size dimension of three juvenile fish species in a tidal mudflat in southeastern Brazil. Marine Biology, 161: 543-550.

Planqué, B., C. Loots, P. Petitgas, U. Lindstrøm \& S. Vaz. 2011. Understanding what controls the spatial distribution of fish populations using a multi-model approach. Fisheries Oceanography, 20: 1-17.

Platell, M. E. \& I. C. Potter. 2001. Partitioning of food resources amongst 18 abundant benthic carnivorous fish species in marine waters on the lower west coast of Australia. Journal of Experimental Marine Biology and Ecology, 261: 31-54.

Ramos, J. A. A., M. Barletta, D. V. Dantas, A. R. A. Lima \& M. F. Costa. 2014. Trophic niche and habitat shifts of sympatric Gerreidae. Journal of Fish Biology, 85: 1446-1469.

Ricklefs, R. E. 2003. A Economia da Natureza, 5. ed Rio de Janeiro, Guanabara Koogan, 503p.

Rocha, M. S. P., J. S. Mourão, W. M. S. Souto, R. R. D. Barboza \& R. R. N. Alves. 2008. O uso dos recursos pesqueiros no estuário do rio Mamanguape, estado da Paraíba, Brasil. Interciencia, 33 : 903-909. 
Schafer, L. N., M. E. Platell, F. J. Valesini \& I. C. Potter. 2002. Comparisons between the influence of habitat type, season and body size on the dietary compositions of fish species in nearshore marine waters. Journal of Experimental Marine Biology and Ecology, 278: 67-92.

Smith, J. A., L. J. Baumgartner, I. M. Suthers \& M. D. Taylor. 2011. Generalist niche, specialist strategy: the diet of an Australian percichthyid. Journal of Fish Biology, 78: 1183-1199.

Tapia-García, M. \& G. Ayala-Pérez. 1996-1997. Clave para la determinación de las especies de mojarras de México (Pisces: Gerreidae). Revista de Biologia Tropical, 44/45: 519-526.

Teixeira, R. L. \& J. L. Helmer. 1997. Ecology of young mojarras (Pisces: Gerreidae) occupying the shallow waters of a tropical estuary. Revista Brasileira de Biologia, 57: 637-646.

Temperoni, B., M. D. Viñas \& C. C. Buratti. 2013. Feeding strategy of juvenile (age-0 + year) Argentine hake Merluccius hubbsi in the Patagonian nursery ground. Journal of Fish Biology, 83: 1354-1370.
Xavier, J. H. A., C. A. M. M. Cordeiro, G. D. Tenório, A. F. Diniz, E. P. N. P. Júnior, R. S. Rosa \& I. L. Rosa. 2012. Fish assemblage of the Mamanguape Environmental Protection Area, NE Brazil: abundance, composition and microhabitat availability along the mangrove-reef gradient. Neotropical Ichthyology, 10: 109-122.

Zar, J. H. 2010. Biostatistical analysis. 5th ed.Upper Saddle River, NJ, Prentice Hall, 944p

Submitted March 30, 2015 Accepted December 15, 2015 by Francisco Araújo 